\title{
Effects of sublethal doses of selected botanical molluscicides on oxygen consumption of the brown garden snail, Eobania vermiculata.
}

\author{
Samir Mohamed H. Beltagi, Mohammed Salah. Ab. Ab. Al-Shinnawy, Nabawy \\ Abdel-Rahman I. Elkattan and Hany Nady Yousef \\ Department of Biological and Geological Sciences, Fac. of Education, Ain Shams \\ University
}

\begin{abstract}
Laboratory bioassays were carried out for evaluating the efficacy of certain plant materials including Nicotine, Thymol, Menthol, Caffeine and Camphor as molluscicides against the brown garden snail, Eobania vermiculata using the topical application method. The obtained results proved that Nicotine and Thymol were the most promising from the molluscicidal point of view with $\mathrm{LD}_{50} 204.02$ and $551.20 \mu \mathrm{g} /$ snail for the two materials, respectively. The effects of sublethal doses $\left(\mathrm{LD}_{25}\right.$ and $\left.\mathrm{LD}_{50}\right)$ of the most potent materials, Thymol and Nicotine, on the oxygen consumption of E. vermiculata snails after 1,7 and 15 days post treatment were evaluated. Results indicated that only snails treated with $\mathrm{LD}_{50}$ Thymol showed significant decrease in their oxygen uptake; while all the other treatments stimulated significant increase in the oxygen consumption along the three periods of estimation. This stimulation was most pronounced with the low sublethal doses of the both examined botanical molluscicides. The succession of time post exposure did not enable the treated snails to eliminate the adverse effects of the applied materials.
\end{abstract}

Depending on the results of the current investigation, we can conclude that the both examined botanical materials, Thymol and Nicotine, are effective in killing the agricultural pest $E$. vermiculata but further studies are needed to evaluate the efficacy of these materials as safe and economic molluscicides in the field.

Keywords: Molluscicides; Thymol; Nicotine; Snails; Eobania vermiculata; Oxygen Consumption.

\section{Introduction}

In Egyptian fields, the terrestrial snail, $E$. vermiculata, family Helicidae, is considered as one of the most agricultural pests causing a great damage to all plant parts of different crops (El-Okda, 1979 and Mahrous et al., 2002).

Application of synthetic molluscicides is remaining the most effective method for controlling mollusk pests, particularly over large areas (Radwan et al., 1992; Schuytema et al, 1994 and Heiba et al, 2002). However, their immense use has a harmful effect on non-target species and lead to pollution of the environment (Godan, 1983). Therefore, much effort has been focused on plant materials for potential uses as commercial pesticides in the hope that they might provide cheap, locally produced, biodegradable, environmentally safe and effective control agents.

Oxygen uptake is one of the best indicators of the overall metabolic activities of an organism (Von Brand et al., 1949). Therefore, beside the conventional bioassay methods for testing molluscicidal action, respirometry can be used as a practical, sensitive and accurate method for the evaluation of molluscicides (Abel-Raheem et al., 1980).

Several studies dealt with the impact of different chemical compounds on the 
oxygen uptake of snails and slugs (Bharathi and Prasada, 1989; Christian and Tesfamichael, 1990; Nair et al., 1995). To the best of our knowledge, regarding the plant origin molluscicides, very little work has been carried out on this respect (Clark and Appleton, 1996). The current investigation aims to study the influence of sublethal doses of two potent botanical molluscicides (Thymol and Nicotine) on the oxygen consumption of $E$. vermiculata snails at different time intervals of exposure.

\section{Materials and methods}

Collection and adaptation of snails:

Adult specimens (20-30 mm shell diameter) of the land snail, E. vermiculata were collected from Al-Montazah Park, Alexandria governorate during spring 2010. The collected snails were transferred in cloth sacs to the laboratory and kept in aerated cages $(40 \times 30 \times 30 \mathrm{~cm}$, with 100 individuals per cage) for two weeks to acclimatize with the laboratory conditions (26-30 ${ }^{\circ} \mathrm{C}$ and $\left.62 \pm 2 \mathrm{RH}\right)$. These snails were supplied with fresh lettuce leaves three times a week.

\section{Plant materials:}

Five plant materials were used in the present study: Nicotine $\left(\mathrm{C}_{10} \mathrm{H}_{14} \mathrm{~N}_{2}\right.$, MW 162.23, purity $99 \%)$, Caffeine $\left(\mathrm{C}_{8} \mathrm{H}_{10} \mathrm{~N}_{4} \mathrm{O}_{2}, \quad \mathrm{MW}\right.$ 194.19, purity 99\%), Thymol $\left(2-\left[\left(\mathrm{CH}_{3}\right)_{2} \mathrm{CH}\right]\right.$ $\mathrm{C}_{6} \mathrm{H}_{3}-5-\left(\mathrm{CH}_{3}\right) \mathrm{OH}, \quad \mathrm{MW} 150.22$, purity 99.5\%), Menthol $\left(\mathrm{C}_{10} \mathrm{H}_{20} \mathrm{O}\right.$, MW 156.27, purity $99 \%)$ and Camphor $\left(\mathrm{C}_{10} \mathrm{H}_{16} \mathrm{O}\right.$, MW 152.23 , purity $95 \%)$. They were prepared in Dimethyl Sulfoxide [DMSO] $\left(\left(\mathrm{CH}_{3}\right)_{2} \mathrm{SO}\right.$, MW 78.13, purity 99\%) which causes little distress to slugs and snails and has been shown to be the most appropriate solvent for topical application (Young and Wilkins, 1989 ; Radwan et al., 2008), and serially diluted with the same solvent to achieve the desired concentrations. Plant materials and DMSO were purchased from Sigma-Aldrich Company.

\section{Bioassay:}

Topical application, the method of Hussein et al. (1994), was used. Preliminary experiments were carried out to establish the effective range concentration of the tested plant materials. The tested concentrations were: $10,15,20,25,30,40$ and $50 \mathrm{mg} / \mathrm{ml}$ for Thymol, 3, 5, 7, 10, 13, $16,20,23$ and $27 \mathrm{mg} / \mathrm{ml}$ for Nicotine, 15 , $20,30,45,60,80$ and $90 \mathrm{mg} / \mathrm{ml}$ for camphor, 10, 25, 40, 50, 60, 80 and 90 $\mathrm{mg} / \mathrm{ml}$ for Menthol and 10, 15, 20, 25, 35, $40,45,50$ and $60 \mathrm{mg} / \mathrm{ml}$ for Caffeine. The tested dose $(30 \mu \mathrm{l})$ was gently applied on the surface of the snail's body inside the shell using a micropipette; while control snails were treated with DMSO. Snails were kept in plastic boxes $(10 \times 20 \times 10 \mathrm{~cm})$ covered with cloth netting secured with rubber bands to prevent snails from escaping. They were fed on fresh lettuce leaves after $24 \mathrm{hr}$ of treatment. The numbers of dead animals were recorded 48 $\mathrm{hr}$ after treatment. The test was replicated 4 times using 10 animals for each concentration.

Measurement of Oxygen consumption:

Oxygen uptake of $E$. vermiculata snails was determined using Warburg's manometric technique (Umbreit $\boldsymbol{e t}$ al. 1964) using 50 $\mathrm{ml}$ capacity vessels each containing a single snail. $\mathrm{CO}_{2}$ was absorbed by freshly prepared $0.4 \mathrm{ml} 10 \% \mathrm{KOH}$ placed in the side arm with a filter paper fan (Whatman No. 1) to increase the absorbent surface. A thermobarometer consisting of an empty flask containing only $\mathrm{KOH}$ was included in each experiment to compensate for shortterm fluctuations in atmospheric pressure. In each experiment, six flasks were submerged in a water bath maintained at $28 \pm 0.01{ }^{\circ} \mathrm{C}$ and an equilibrium period of one hour was allowed before closing the stopcock of the manometer. Readings were recorded at 20-minute intervals for twohour period. The volume of the experimental snails was determined by displacement method and their weight was measured carefully using analytical digital balance with $0.01 \mathrm{mg}$ accuracy (model JK200, Komatsu, Japan). Oxygen uptake was expressed as $\mathrm{ml} \mathrm{O}_{2} / \mathrm{g} \mathrm{Wet} \mathrm{wt/h}$. 
Statistical analysis:

Percentage mortality rates were corrected using Abbott's formula (Abbott, 1925); toxicity parameters for each tested plant material were determined by the probit analysis method of Finney (1971) on Windows ${ }^{\circledR}$ platform Version 2002. The values of oxygen consumption were represented as means $\pm \mathrm{SD}$ and the differences were analyzed for significance by Student's (t) test using statistical analysis program, Biostat-2006 on Windows ${ }^{\circledR}$ platform Version 2002. Average stimulation (+) or inhibition (-) of oxygen consumption in percent of control was calculated according to the following equation:

$$
\text { Change } \%=\frac{\text { Test }- \text { control }}{\text { Control }} \times 100
$$

\section{Results}

The data obtained from examining the molluscicidal activity of the studied botanical materials showed that Thymol and Nicotine were the most potent with $\mathrm{LD}_{50}$ of 204.02 and $551.20 \mu \mathrm{g} /$ snail, respectively (Table 1).

\section{Table 1.}

Molluscicidal activity of selected botanical materials against $E$. vermiculata snails using the topical application method.

\begin{tabular}{|c|c|c|c|}
\hline $\begin{array}{c}\text { Botanical } \\
\text { material }\end{array}$ & $\begin{array}{c}\mathrm{LD}_{25} \\
(\mu \mathrm{g} / \text { snail }) \text { after } 48 \mathrm{~h}\end{array}$ & $\begin{array}{c}\mathrm{LD}_{50}{ }^{\mathrm{a}} \\
(\mu \mathrm{g} / \text { snail }) \text { after } 48 \mathrm{~h}\end{array}$ & Confidence limits for $\mathrm{LD}_{50} \mathrm{~b}$ \\
\hline Thymol & 377.63 & 551.20 & $491.65-609.33$ \\
\hline Nicotine & 116.17 & 204.02 & $173.32-233.47$ \\
\hline Camphor & 893.56 & 1354.07 & $1210.68-1509.42$ \\
\hline Menthol & 673.75 & 1252.17 & $1065.13-1466.92$ \\
\hline Caffeine & 524.30 & 932.37 & $822.19-1055.62$ \\
\hline
\end{tabular}

${ }^{a}$ Means based on 4 replicates $(n=4), 10$ animals each.

${ }^{b}$ Lower and upper Limits for $L D_{50}$ at $95 \%$ confidence 


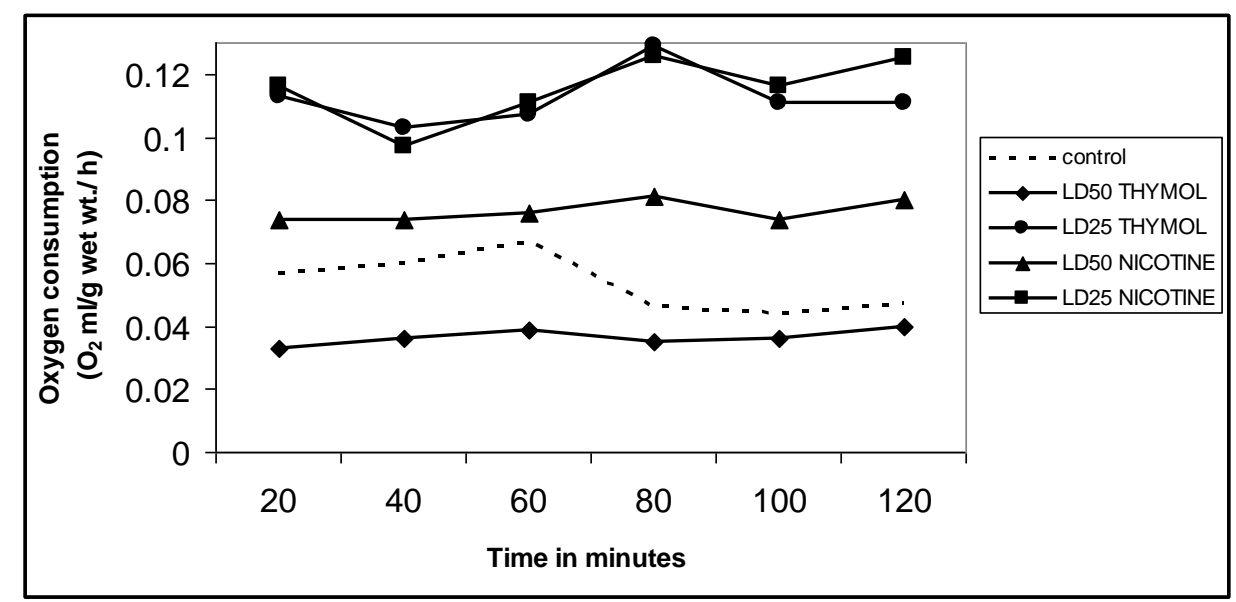

Fig 1. Mean oxygen consumption of E. vermiculata snails post 1 day of treatment with sublethal doses of Thymol and Nicotine. Each point represents the mean value of 6 determinations.

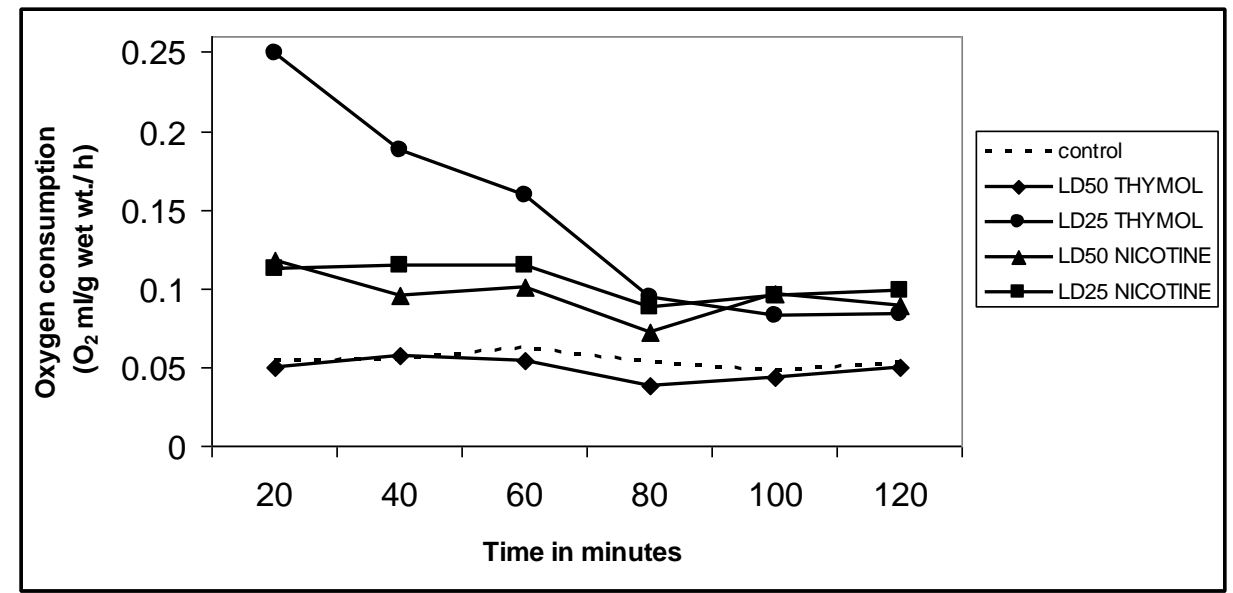

Fig 2. Mean oxygen consumption of E. vermiculata post 7 days of treatment with sublethal doses of Thymol and Nicotine. Each point represents the mean value of 6 determinations.

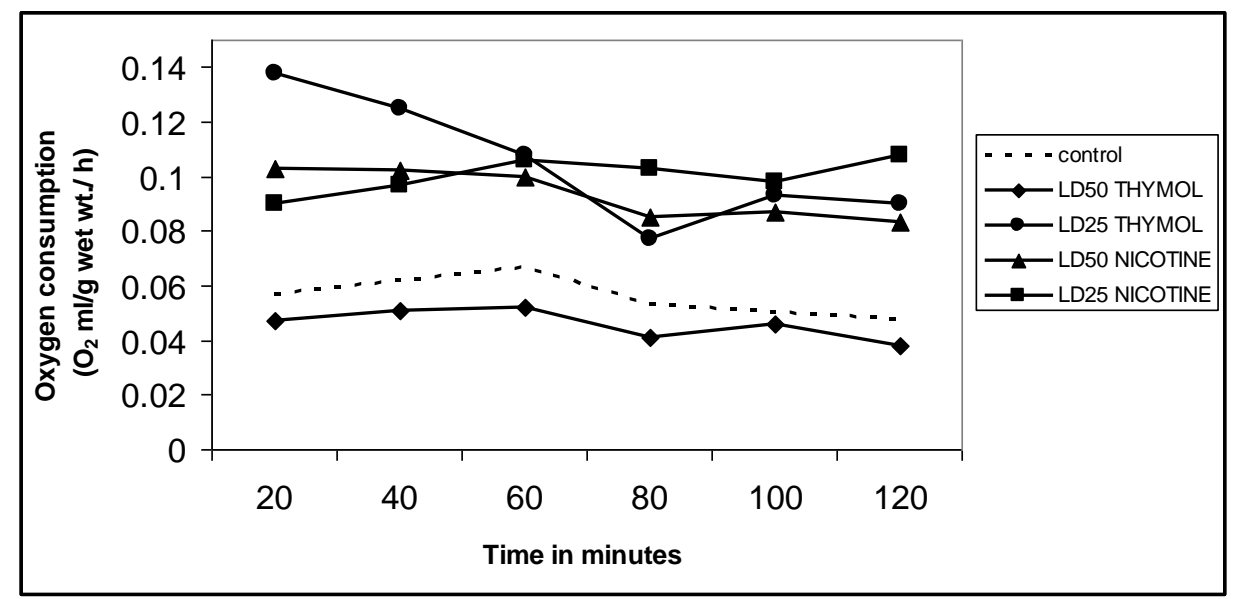

Fig 3. Mean oxygen consumption of E. vermiculata post 15 days of treatment with sublethal doses of Thymol and Nicotine. Each point represents the mean value of 6 determinations. 
Table 2.

The effect of sublethal doses of Thymol and Nicotine on the oxygen consumption $(\mathrm{ml} / \mathrm{g}$. wet. wt./h) of E. vermiculata snails at three time intervals post exposure.

\begin{tabular}{|c|c|c|c|c|}
\hline $\begin{array}{l}\text { Time } \\
\text { interval } \\
\text { post } \\
\text { exposure } \\
\text { (Days) }\end{array}$ & $\begin{array}{l}\text { Examined } \\
\text { group }\end{array}$ & $\begin{array}{l}\text { Minimum and } \\
\text { maximum } \\
\text { readings of } \\
\text { oxygen } \\
\text { consumption }\end{array}$ & Mean \pm S.D. ${ }^{\mathrm{a}}$ & $\begin{array}{c}\text { Average } \\
\text { stimulation (+) or } \\
\text { inhibition }(-) \text { of } \\
\text { oxygen } \\
\text { consumption in } \\
\text { percent of control }\end{array}$ \\
\hline \multirow{5}{*}{1} & Control & $0.044-0.067$ & $0.054 \pm 0.009$ & \\
\hline & $\mathrm{LD}_{50}$ Thymol & $0.033-0.040$ & $0.037 \pm 0.003 *$ & -31.48 \\
\hline & $\mathrm{LD}_{25}$ Thymol & $0.103-0.129$ & $0.112 \pm 0.009 *$ & +107.41 \\
\hline & $\mathrm{LD}_{50}$ Nicotine & $0.074-0.081$ & $0.077 \pm 0.003 *$ & +42.59 \\
\hline & $\mathrm{LD}_{25}$ Nicotine & $0.097-0.126$ & $0.115 \pm 0.011 *$ & +112.96 \\
\hline \multirow{5}{*}{7} & Control & $0.048-0.063$ & $0.054 \pm 0.005$ & \\
\hline & $\mathrm{LD}_{50}$ Thymol & $0.038-0.057$ & $0.049 \pm 0.007$ & -9.26 \\
\hline & $\mathrm{LD}_{25}$ Thymol & $0.083-0.249$ & $0.143 \pm 0.068 *$ & +164.82 \\
\hline & LD $_{50}$ Nicotine & $0.072-0.118$ & $0.096 \pm 0.015 *$ & +77.77 \\
\hline & $\mathrm{LD}_{25}$ Nicotine & $0.088-0.115$ & $0.104 \pm 0.011 *$ & +92.59 \\
\hline \multirow{5}{*}{15} & Control & $0.048-0.067$ & $0.056 \pm 0.007$ & \\
\hline & $\mathrm{LD}_{50}$ Thymol & $0.038-0.052$ & $0.046 \pm 0.006 *$ & -17.86 \\
\hline & $\mathrm{LD}_{25}$ Thymol & $0.077-0.138$ & $0.105 \pm 0.023 *$ & +87.50 \\
\hline & LD $_{50}$ Nicotine & $0.083-0.103$ & $0.093 \pm 0.009 *$ & +66.07 \\
\hline & $\mathrm{LD}_{25}$ Nicotine & $0.090-0.108$ & $0.100 \pm 0.007 *$ & +78.57 \\
\hline
\end{tabular}

${ }^{a}$ Mean of six experiments (6 snails each) \pm standard deviation.

* Statistically significant $(p \unlhd 0.05)$ as compared with the controls. 


\section{Discussion}

Study of the physiology of snails might yield important clues for development of chemical means of control. Theoretically, it appears likely that snails may be killed by the use of compounds interfering with cellular respiratory mechanisms (Von Brand et al., 1948). Therefore estimating the oxygen consumption as an important mean for evaluating the molluscicidal activity has been carried out by many authors (Bharathi and Prasada, 1989; Christian and Tesfamichael, 1990; Clark and Appleton, 1996).

Previous investigation carried out by Kerkut and Laverack (1956) on the respiration of Helix pomatia snails, family Helicidae, showed considerable short-term fluctuations in the respiratory activity. Therefore, in the current study, the oxygen uptake of E. vermiculata snails in response to the influence of the two potent botanical molluscicides, Thymol and Nicotine, was recorded along a period of two hours. The results obtained by the current study indicated that treatment of E. vermiculata snails with $\mathrm{LD}_{50}$ Thymol caused a marked and long lasting decline in oxygen consumption. This finding correlates with that of Ishak and Mohamed, 1975 who reported that exposing of Biomphalaria alexandrina snails to sublethal concentrations of copper sulphate and Bayloscide caused a marked reduce in oxygen uptake in direct and prolonged exposure periods. Similar results were obtained by Von Brand et al. (1949) on Australorbis glabratus snails treated with $\alpha$-nitrostilbene. Also Sivaramakrishna et al. (1991) confirmed that the rate of oxygen consumption of the freshwater snail, Pila globosa and the Mussel, Lamellidens marginalis decreased in response to both lethal and sublethal concentrations of mercury.

The interpretation of this inhibition in oxygen uptake may be attributed to one or more of the following mechanisms: firstly, the tested compound inhibited the enzyme systems involved in oxygen consumption.
This postulation was supported by the study of Von Brand et al., 1949; Ishak et al., 1970; Bharathi and Prasada, 1989. The second explanation returns this inhibiting effect to the cutaneous respiration that is considered the most important in meeting the oxygen requirements of pulmonates (Alberts, 1966). After dermal application, the primary targets for molluscicides are the epithelial cells of the skin. Therefore these molluscicides may damage the cutaneous respiration causing changes in the oxygen uptake. Finally, molluscicides may affect the oxygen carrier protein, hemocyanin, and thus inhibit the respiration process. This assumption preassumed by Christian and Tesfamichael, 1990.

On the other hand, significant stimulation in the respiration of $E$. vermiculata snails was recorded in response to all the other treatments, in particular the low sublethal doses, along the three periods of estimation. This result is in agreement with that of Bharathi and Prasada, 1989 who recorded significant increase in the oxygen uptake of the freshwater snail Thiara torulosa in response to sublethal concentrations of three organophosphorus insecticides. The same author mentioned that the increased rate of oxygen uptake may be considered as one of the earliest symptoms of pesticide poisoning. In addition, Clark and Appleton (1996) indicated that low sublethal concentrations of aqueous suspensions of the plant Apodytes dimidiate caused significant increase in the oxygen consumption of the snail Helisoma duryi relative to the controls.

Detoxification processes are reactions to limit damage by toxins or to excrete them. This process includes: (i) enzymatic reactions leading to the biotransformation of chemicals by oxidation; (ii) hydrolysis or conjugation; and (iii) several other biochemical processes, such as the induction of stress proteins or metallothioneins involved in direct interactions with the toxins and maintenance of intracellular homoeostasis (Barker, 2002). Under stress conditions, the snails need more energy to detoxify the 
toxicants and to overcome the induced stress. This may explain the high oxygen demand to comply the excessive need for energy.

On conclusion the both examined botanical materials, Thymol and Nicotine, are effective in killing the agricultural pest $E$. vermiculata and the sublethal doses of them cause adverse effects on the snail's respiration, either by inhibition or stimulation, that reflect interruption of the snail's internal physiology but further studies are needed to evaluate the efficacy of these materials as safe and economic molluscicides in the field.

\section{References}

1. Abbott W S., (1925). A method of computing the effectiveness of an insecticide. J. Econ. Entomol., 18: 265-267.

2. Abel Raheem K, El-Gindy $\mathbf{H}$ and AlHassan J., (1980). Interrelationship of molluscicidal concentration and temperature on the respiration of Bulinus truncates. Hydrobio., 74: 11-15.

3. Alberts L E., (1966). Some aspects of the respiratory physiology of three south African freshwater pulmonate snails, Bulinus (physopsis) africanus (krauss), Bulinus tropicus (krauss) and Lymnaea natalensis (krauss). South. Afr. J. Sci., 62: 215-223.

4. Barker G M., (2002). Mollusks as crop pests. CABI publishing, Wallingford, Oxon, UK, pp. 10.

5. Bharathi Ch and Prasada Rao D G V., (1989). Toxicity to and oxygen consumption of the freshwater snail Thiara (Stenomelania) torulosa (Bruguiere) in relation to organophosphorus insecticide exposure. Bull. Environ. Contam. Toxicol., 42(5): 773-777.

6. Christian $\mathbf{F} \mathbf{A}$ and Tesfamichael $\mathbf{T}$ M., (1990). Oxygen uptake of Pseudosuccinea columella and Fossaria cubensis treated with sublethal concentrations of CUTRINE-PLUS, an algicide. Bull. Environ. Contam. Toxicol., 45: 336-342.

7. Clark T E and Appleton C C., (1996). The physiological effects of aqueous suspensions of plant molluscicides on Helisoma duryi (gastropoda: planorbidae). J. Moll. Stud., 62: 459-476.

8. El-Okda M M K., (1979). Land snails of economic importance of Alexandira region with some notes on the morphological features, classification, economic damage and population of ornamental plants. Agric. Res. Rev., 57: 125130.

9. Finney D J., (1971). Probit analysis., 3rd Ed. Cambridge Univ. Press, London. Pp. 318329.

10.Godan D., (1983). Pest slugs and snails, Biology and control, springer-Verlag, Berlin, pp. 443.

11. Heiba F N, Al-Sharkawy I M and Al-Batal A A., (2002). Effects of the insecticide Lannate, on the land snails, Eobania vermiculata and Monacha contiana, under laboratory conditions. J. Biol. Sci., 2(1): 8-13.

12. Hussein H I, Kamel A, Abou-Zeid M, ElSebae A H and Saleh M A., (1994). Uscharin, the most potent molluscicidal compound tested against land snails. J. Chem. Ecol., 20: 135-140. 13. Ishak M M and Mohamed A M., (1975). Effect of sublethal doses of copper sulphate and bayluscide on survival and oxygen consumption of the snail Biomphalaria alexandrina. Hydrobio., 47 (3-4): 499-512.

14. Ishak M M, Sharaf A A, Mohamed A M and Mousa A H., (1970). Studies on the mode of action of some molluscicides on the snail, Biomphalaria alexandrina: I. Effect of bayluscide, sodium pentachlorophenate and copper sulphate on succinate, glutamate and reduced TMPD oxidation. Comp. Gen. Pharmacol., 1(2): 201-208.

15. Kerkut G A and Laverack M S., (1956). The respiration of Helix pomatia, a balance sheet. Exp. Biol., 34:97-105.

16. Mahrous M E, Ibrahim M H and AddelAal E M., (2002). Occurrence, population density and importance value of land snails infesting different crops in Sharkia Governorate, Egypt. Zagazg J. Agric. Res., 29(2): 613-629.

17. Nair G A, Mobamed A I and Bhuyan K C., (1995). Comparative effects of chemical pesticides on survival, body mass and respiration of the pulmonate slugs Milax rusticus and Milax sowerbyc. J. Afr. Zool., Belgium, 109(2): 141-149.

18. Radwan M A, El-Wakil H B and Osman K A., (1992). Toxicity and biochemical impact of certain oxime carbamates pesticide against terrestrial snail, Theba pisana (Müller). J. Environ. Sci. Health, B27(6): 759-773.

19. Radwan M A, Essawy A E, Abdelmeguied N E, Hamed S S and Ahmed A E., (2008). Biochemical and histochemical studies on the digestive gland of Eobania vermiculata snails treated with carbamate pesticides. Pest. Biochem. Physiol., 90: 154-167.

20.Schuytema G S, Nebeker A V and Griffis W L., (1994). Effects of dietary exposure to 
21.forest pesticides on the brown garden snail, Helix aspersa (Muller). Arch. Environ. Contam. Toxicol., 26: 23-28.

22.Sivaramakrishna B, Radhakrishnaiah K and Suresh A., (1991). Assessment of mercury toxicity by the changes in oxygen consumption and ion levels in the freshwater snail, Pila globosa and the Mussel, Lamellidens marginalis. Bull. Environ. Contam. Toxicol., 46: 913-920.

23. Umbreit W W, Burris $\mathbf{R} \mathbf{H}$ and Stauffer $\mathbf{J}$ F., (1964). Manometric techniques. 4th Ed. Burgess Pub. Co., Minneapolis.
24. Von Brand T, Mehlman B and Nolan M O., (1949). Influence of some potential molluscicides on the oxygen consumption of Australorbis glabratus. J. Parasitol., 35: 475481.

25. Von Brand T, Nolan M O and Mann E R., (1948). Observations on the respiration of Australorbis glabratus and some other aquatic snails. Biol. Bull., 95: 199-213.

26. Young A G and Wilkins R M., (1989). A new technique for assessing the contact toxicity of molluscicides to slugs. J. Moll. Stud., 55: 533-536. 


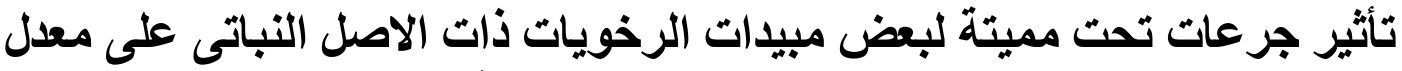

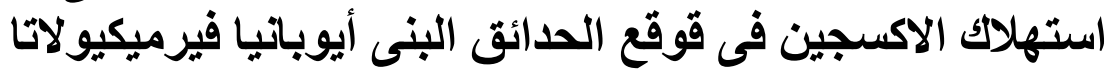

\author{
سمير محمد حسن بلتاجى، محمد صلاح عبد الحميا عبدالله الثناوى، نبوى عبد الرحمن إبراهيم القطان، هانى \\ نادى يوسف عبل \\ قسم العلوم البيولوجية والجيولوجية ـ كلية التربية ـ جامعة عين شمس- القاهرة ـ مصر
}

تم اجر اء اختبار ات معملية لتقييم فعالية بعض المواد النباتية (النيكوتين، الثيمول، المنتول، الكافيين،

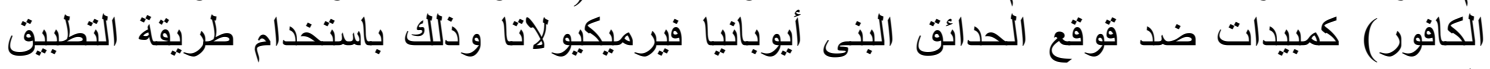

و أثثتت النتائج أن مادتى النيكوتين و الثيمول هما الاكثر فعالية كمبيدات رخويات، حيث كانت قيمة

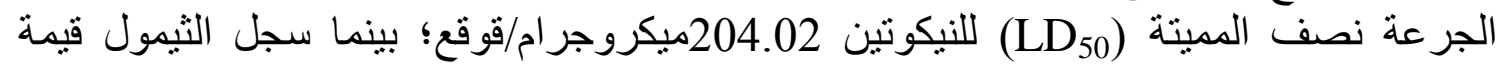
قدر ها 551.20 ميكروجرام/قوقع. تم تحضير جرعات تحت مميتة (LD (LD

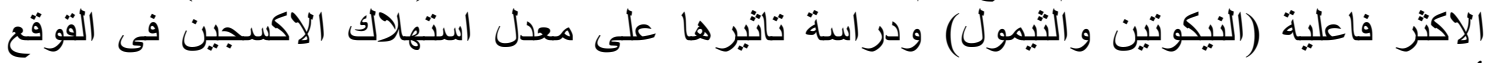

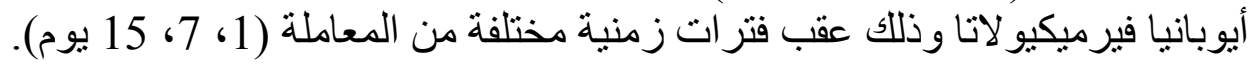

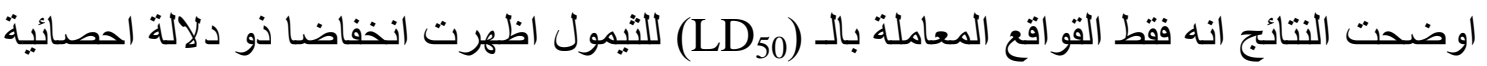

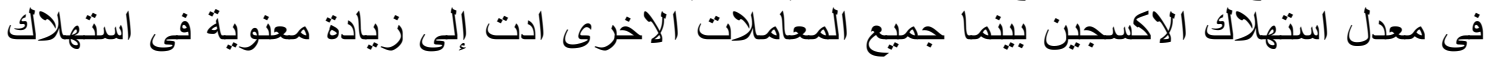

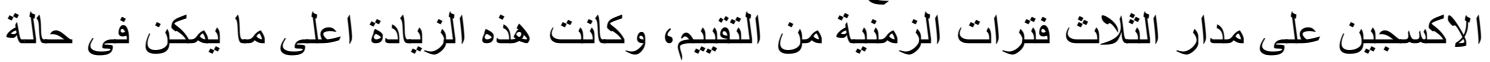

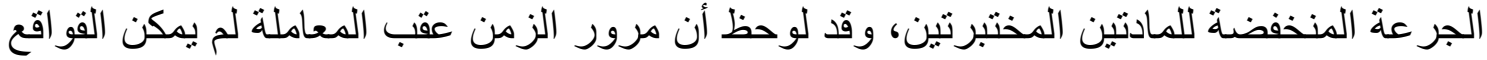
التى تم معاملتها من التخلص من التاثير ات السلبية للمو اد المدروسة التهن.

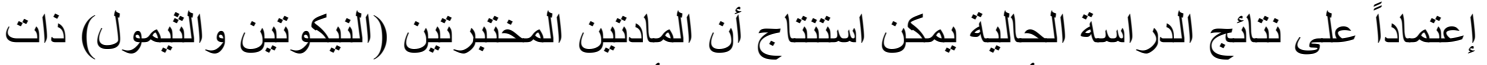

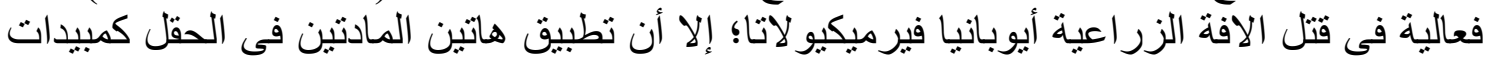

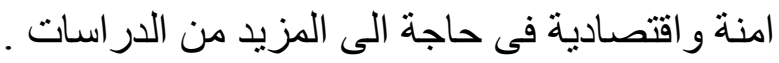

